\title{
Quinolones: Synthesis and Antibacterial Activity
}

\author{
Pintilie Lucia \\ National Institute for Chemical-Pharmaceutical \\ Research and Development, Bucharest \\ Romania
}

\section{Introduction}

After the concept of selective toxicity in chemotherapy was introduced at the beginning of the $20^{\text {th }}$ century, (Ehrlich, 1913), classes of substances with antibacterial properties, produced by microorganisms or created through synthesis were obtained. After the discovery of penicillin, the first antibiotic introduced in clinical use in man in 1940s, a large number of different types of antibiotics were produced. Antibiotics such as beta-lactams, macrolides, aminoglycozides and tetracyclines were discovered and introduced during an extremely short period. These were obtained either by isolation from fungi or by chemically modification of the naturally isolated substrates. These dominated the antimicrobial industry, while synthetically obtained substances only played a minor role. (Chu \& Fernandes, 1991)

In 1962, G. Y. Lesher and his collaborators introduced the first quinolone derivative, nalidixic acid (1-ethyl-1,4-dihydro-7-methyl-4-oxo-1,8-naphthyridine-3-carboxilyc acid), (1, Lesher et al. 1962) which had moderate activity against gram-negative organisms and was used for treating urinary tract infections. In the following years, a large gamma of derivatives from common elements were synthesized, which could be grouped by: cinoline (cinoxacin), pyrido-pyrimidine (pipemidic acid; piromidic acid), naphthyridine (nalidixic acid) and quinolones (oxolinic acid, miloxacin, tioxacin, etc.). These derivatives, with differentiated structures, have 2 common pharmacological properties, which allowed them to be classified as first generation biologically active derivatives with quinolone structure. The two common characteristics for first generation quinolones are:

- a narrow antibacterial spectrum, designed especially for enterobacteriaceae;

- a pharmacokinetic which allows for rapid elimination and reduced tissue absorption, only allowing them to be used as urinary antiseptics.<smiles>CCn1cc(C(=O)O)c(=O)c2ccc(C)nc21</smiles>

Nalidixic Acid<smiles>CCn1nc(C(=O)O)c(=O)c2cc3c(cc21)OCO3</smiles>

Cinoxacine<smiles>CCn1cc(C(=O)O)c(=O)c2cc3c(cc21)OCO3</smiles>

Oxolinic Acid 
<smiles>COn1cc(C(=O)O)c(=O)c2cc3c(cc21)OCO3</smiles>

Miloxacine<smiles>CCn1cc(C(=O)O)c(=O)c2cnc(N3CCCC3)nc21</smiles>

Piromidic Acid<smiles>CCn1cc(C(=O)O)c(=O)c2cnc(N3CCNCC3)nc21</smiles>

Pipemidic Acid

Fig. 1. First-generation quinolones.

The success of first generation quinolones spurred the research in this area, which led to the obtainment through synthesis, after 1980, of a new series of compounds with stronger antibacterial properties and a broader spectrum of antibacterial activity which included gram positive and gram negative organisms, and which where defined by their ability to be applied on all localized infections. Koga and his collaborators introduced Norfloxacin into clinical use in 1980, the first quinolone with a fluorine atom substituted at the C-6 position and a piperazine C-7. Norfloxacin (Koga et al. 1980) was the first quinolone with increased antimicrobial activity, acting on a large spectrum of gram positive and gram negative microorganisms, including Pseudomonas aeruginosa.<smiles>CCCCCCCCn1cc(C(=O)O)c(=O)c2cc(F)c(N3CCNCC3)cc21</smiles><smiles>CCn1cc(C(=O)O)c(=O)c2cc(F)c(N3CCN(C)CC3)c(F)c21</smiles><smiles>CCn1cc(C(=O)O)c(=O)c2cc(F)c(N3CCNCC3)nc21</smiles><smiles>CCn1cc(C(=O)O)c(=O)c2cc(F)c(N3CCN(C)CC3)cc21</smiles>

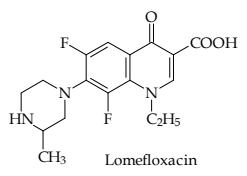<smiles>CC1COc2c(N3CCN(C)CC3)c(F)cc3c(=O)c(C(=O)O)cn1c23</smiles><smiles>O=C(O)c1cn(C2CC2)c2cc(N3CCNCC3)c(F)cc2c1=O</smiles><smiles>CN1CCN(c2cc3c(cc2F)c(=O)c(C(=O)O)cn3C)CC1</smiles><smiles></smiles>

Fig. 2. Second-generation quinolones.

Research in the field of derivatives with a quinolone structure have lead to new compounds obtained recently, which have been classified as third and fourth generation systemic quinolones, largely effective against Staphilococcus aureus. Their large antibacterial spectrum includes anaerobes, Chlamydia and Mycoplasma. (Brighty \& Gootz, 2000) 
<smiles>CNC1CCCN(c2c(F)cc3c(=O)c(C(=O)O)cn(C4CC4)c3c2OC)C1</smiles>

Balofloxacin<smiles>CON=C1CC(c2nc3c(cc2F)c(=O)c(C(=O)O)cn3C2CC2)CC1CN</smiles><smiles>CC1COc2c3c(cc(F)c2C2(N)CC2)-c2c(C(=O)O)cn1c2-3</smiles>

Pazufloxacin<smiles>COc1c(N2CCNC(C)C2)c(F)cc2c(=O)c(C(=O)O)cn(C3CC3)c12</smiles>

Gatifloxacin<smiles>C[C@H]1CC(c2c(F)c(N)c3c(=O)c(C(=O)O)cn(C4CC4)c3c2F)C[C@@H](C)N1</smiles>

Sparfloxacin

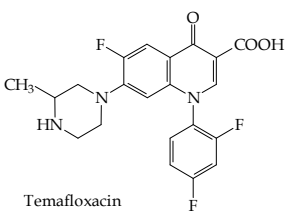

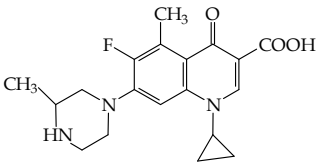

Grepafloxacin<smiles>CC1COc2c(N3CCN(C)CC3)c(F)cc3c(=O)c(C(=O)O)cn1c23</smiles><smiles>NC1CCN(c2nc3c(cc2F)c(=O)c(C(=O)O)cn3-c2ccc(F)cc2F)C1</smiles>

Fig. 3. Third- generation quinolones.

The four generations have the following common aspects: an identical mechanism of action by inhibition the A subunit of DNA-gyrasa, an exclusively chromosomal bacteria resistance and some similar bacteria effects: photo toxicity, neurotoxicity, cartilage toxicity.

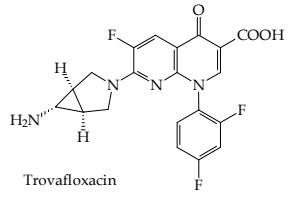<smiles>COc1c(N2C[C@@H]3[C@@H](C)CC[C@@H]3[C@H]2C)c(F)cc2c(=O)c(C(=O)O)cn(C3CC3)c12</smiles>

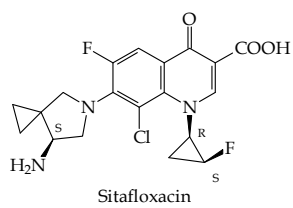

Clinafloxacin Sitafloxacin<smiles></smiles>

Fig. 4. Fourth- generation quinolones.

Until now a large number of antibacterial substances belonging to the above mentioned class have been used in medicine. Quinolones are used when treating infections of the urinary tract, the respiratory tract, intestinal infections, ear/nose/throat infections, STD's, soft tissue and skin infections, meningitis caused by gram negative and Staphilococci bacteria, liver and bile infections, septicemia and endocarditis, prophylaxis and surgical infections and on patients with immune deficiencies. 
The mechanism of action of quinolone antibacterial agents involves the inhibition of DNA gyrase (a bacterial topoisomerase II) resulting in a rapid bactericidal effect.

The antibacterial activity of quinolones (measured in terms of MIC), however, is the result of the combination of bacterial cell penetration and DNA gyrase inhibitory activity. The antibacterial activity of quinolones depends not only on the bicyclic heteroaromatic system combining the 1,4-dihydro-4-pyridine-3-carboxylic acid moiety and an aromatic ring, but also on the nature of the peripheral substituents and their spatial relationships. These substituents exert their influence on bacterial activity by providing additional affinity for bacterial enzimes, enhancing cell penetration or altering the pharmacokinetics.

The research for an ideal quinolone continues worldwide. Such a quinolone must be biologically active on a large spectrum of gram positive and gram negative bacteria, aerobes and anaerobes and mycobacteria, must have as few side effects as possible, excellent solubility in water and oral bioavailability.

In figure 5, the most common synthesized chemical variations obtained during the research for new quinolones with antibacterial activity, are visible.

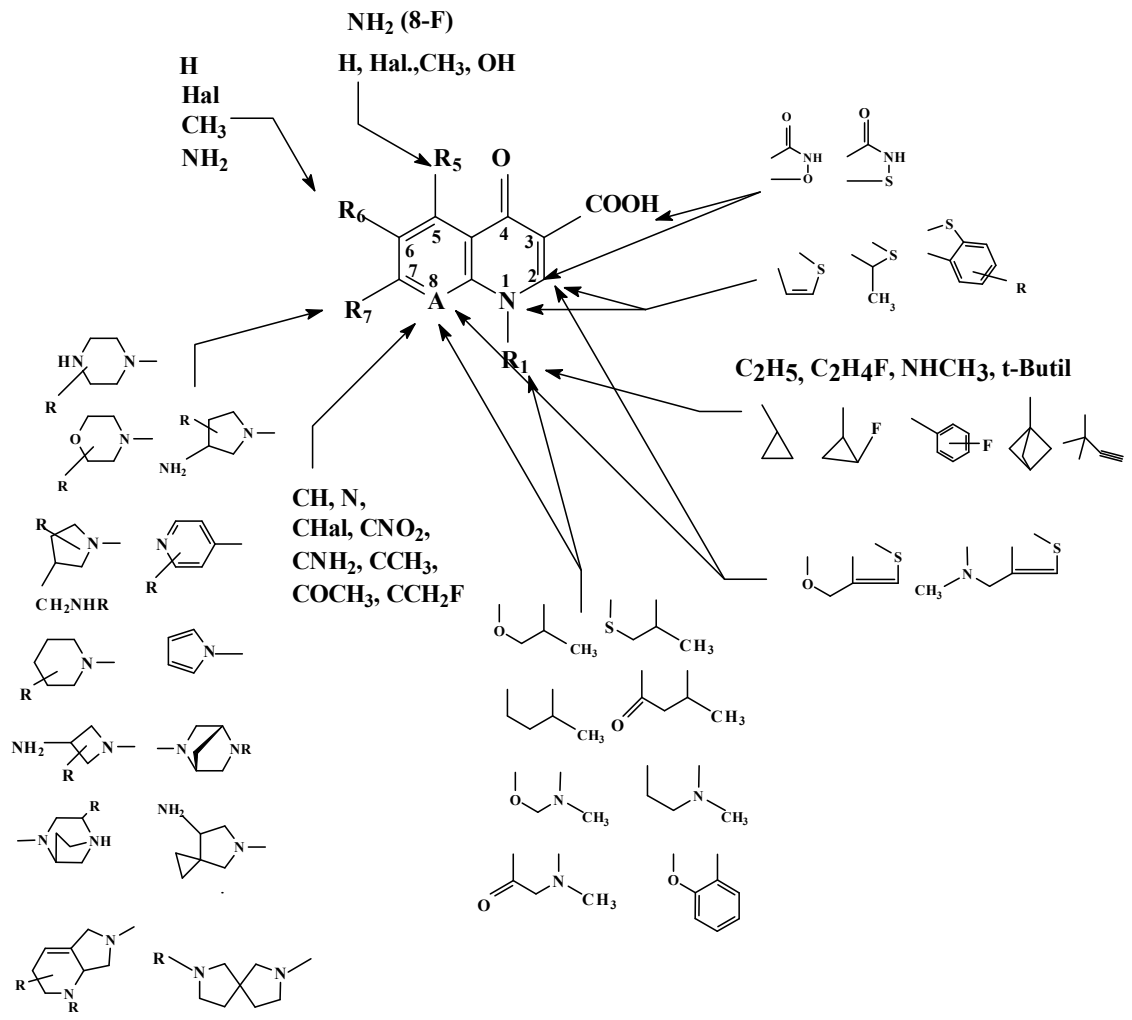

Fig. 5. Structural variations of the most recent quinolones. 


\section{Quinolones: Structural features and method of synthesis}

\subsection{Structural features}

Quinolone derivatives are an important class of antibacterial agents with wide action. Basic structure of these compounds (Figure 6) is a bicyclic structure, which contains a ring of type $A$ 4-piridinona combined with aromatic or heteroaromatic ring $B$. The ring type $A$ 4piridinona is a ring with absolute necessity: an unsaturation in position 2-3, a free acid function in position 3 and a substituent at nitrogen in position 1.

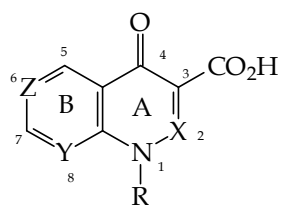

Fig. 6. Basic structure of quinolones.

\subsubsection{Bicyclic quinolones}

\section{Position 1}

The studies on quinolones indicated that in order for the compound to have antibacterial activity, the $\mathrm{N}-1$ position requires a substituent. Many quinolones contain in N-position : ethyl (norfloxacin, pefloxacin, lomefloxacin), fluoroethyl (fleroxacin), vinyl, clloroethyl, trifluoroethyl, aminoethyl, cyclopropyl (ciprofloxacin), $t$-butyl, bicyclopentyl, $p$ fluorophenyl,2,4-difluorophenyl (Scott 1997)

\section{Position 2}

Quinolones contain at C-2 hydrogen $\left(\mathrm{R}_{2}=\mathrm{H}\right)$. The replacement at hydrogen has generally proven to be disadvantageous. However, some compounds containing a suitable C-1, C-2 ringhave recently been shown to possess biological activity. (Figure7 -Segawa 1992) (Figure 8 - Scott 1997)<smiles>[R]c1[X]c2c(c([R3])c1[R])c(=O)c(C(=O)O)c([R])n2[Y]</smiles>

Fig. 7. Basic structure of bicyclic quinolones. 
<smiles></smiles>

$$
\begin{aligned}
& \mathrm{R}=\mathrm{H} \text {, methyl, ethyl, substituted phenyl } \\
& \mathrm{R}_{6}=\mathrm{F}, \mathrm{Cl} \\
& \mathrm{R}_{7}=\text { heterocycle }
\end{aligned}
$$

Fig. 8. 7-Substituted-6-halo-4-oxo-4H-[1,3]-thiazeto[3,2]quinolin-3-carboxilyc acid.

\section{Position 3}

The C-3 carboxylic acid moiety is most commonly encountered. (Chu \&Fernandes1991) . In the late of 1980s, a modification was described that eliminated the need for C-3 carboxylic acid. A fused izothiazolone ring was identified as serving as a carboxylic acid mimic,The compound A-62824 (Figure 9) have been found with biological activity.<smiles></smiles><smiles>O=C(O)c1c(=O)c2cc(F)c(N3CCNCC3)cc2n2c1sc1ccccc12</smiles><smiles>O=C(O)c1c(=O)c2cc(F)c(N3CCNCC3)c3c2n2c(csc12)CO3</smiles>

Fig. 9. Quinolones with sulfur substituent at C-2.<smiles>O=c1[nH]sc2c1c(=O)c1cc(F)c(N3CCNCC3)cc1n2C1CC1</smiles>

Fig. 10. A-62824.

\section{Position 4}

The C-4 oxo group of the quinolones nucleus is generally considered to be essential for antibacterial activity.

\section{Position 5}

The choice of the C-5 substituent appears to be dictated by the the steric regulations and the nature of the N-1 and C-8 substituent (Chu \&Fernandes1991). $\left(\mathrm{R}_{5}=\right.$ methyl, halogen, amino when $X=C F$ ). 


\section{Position 6}

The nature of the C- 6 substituent have a great impact on the DNA-gyrase inhibitory activity and cell penetration. (Domagala et al. 1986). The $\mathrm{R}_{6}$ can be $\mathrm{H}, \mathrm{Cl}, \mathrm{F}, \mathrm{NO}_{2}, \mathrm{NH}_{2}, \mathrm{CN}$, $\left.\mathrm{CH}_{3} \mathrm{SCH}_{3}, \mathrm{COCH}_{3}\right)($ Koga et al. 1980)

\section{Position 7}

The choice of the C-7 substituent is a key issue which continues to guide the design of new antibacterial quinolones. The $R_{7}$ can be substituted/unsubstituted piperazines, aminopyrrolidines, aminoalkylpyrrolidines, (Figure 5) (Chu \& Fernandes 1991) (Scott 1997).

\section{Position 8}

The most common variations at the $\mathrm{C}-8$ position is hydrogen atom $(\mathrm{X}=\mathrm{CH})$ or a nitrogen atom(a naphthyridine) $(\mathrm{X}=\mathrm{N})$. However, compact, liophilic group $\left(\mathrm{X}=\mathrm{CF}, \mathrm{C}-\mathrm{CF}_{3,} \mathrm{CCl}, \mathrm{C}\right.$ $\mathrm{OCH}_{3}$ ) increase the antibacterial activity. (Chu \& Fernandes 1991) (Scott 1997).

\subsection{Method of synthesis}

\section{Gould-Jacobs method}

The quinolones are of synthetic origin. (Chu \& Fernandes, 1991). The most common synthetic methodology to prepare quinolone derivatives is Gould-Jacobs method (Figure 11). This method is used mainly for synthesis of compounds with $\mathrm{N}-1$ alkyl substituents, and consists in the condensation of anilines (II) with diethyl ethoxymethylenemalonate (EMME) and cyclization of the obtained anilinomethylenemalonate. Termal cyclization can be carried out in dowterm (Koga, et al.1980), clorsulfonic acid, oleum acid or a mixture of clorosulfonic acid and oleum acid (Saukaita \& Gupton, 1996). The key intermediary obtained (IV or X) will undergo a alkylation (Koga et al. 1980), cycloalkylation with bromocyclopropane (Kazimierozaack \& Pyznar, 1987), (Sanjose\&Ulpiano 1986), or with 1-bromo1-ethoxy-cyclopropane, arylation with para-nitro-clorofenil or 2,4-dinitro-clorofenil (Raddl \& Zikan, 1989) in order to insert the substituent in position 1 of the quinolone nucleus. The ethyl esther $(\mathrm{V})$ undergoes a hydrolysis reaction, and the quinoline-3-carboxylic acid (VI), following regiospecific substitution of the 7-chloro group leads to the final compounds (VIII). Figure 11 illustrates also, methods for synthesis of 1-cyclopropyl-quinolones starting to anilines of formula II.Anilines (II) is reacted with 1-bromo-1-ethoxy-cyclopropane (Ramos \& Garcia 1994)(Scriewer et al. 1988) or a cyclopropyl-metalic compound (McGuirk 1989). Alternatively, N-ethyl substituted anilines of formula XV may be formed by reductive amination with an appropiate aldehyde and a suitable reducing agent: diborane, palladium on carbon with hydrogen, sodium borohydride or sodium cyanoborohidride (McGuirk 1989) (Ramos 1994). N-isopropyl substituted quinolones may be form by alkylation with isopropylbromide (Pintilie et al. Sept. 2009), (Pintilie et al, oct.2009),(Pintilie et al. 2010), of compounds IV. (Figure 11).

The modified Gould-Jacobs method will also be used, where the diethyl ethoxymethylenemalonate reacts with monosubstituted $\mathrm{N}$ aniline (XVII) (Figure 12). The aniline (XVII) is obtained by reductive amination of ketones and aldehydes with sodium borohydride-acetic acid (Itoh \& Kato 1984) or triacetoxyborohydride. (Pintilie et al.2009). (Pintilie et al. 2010). 


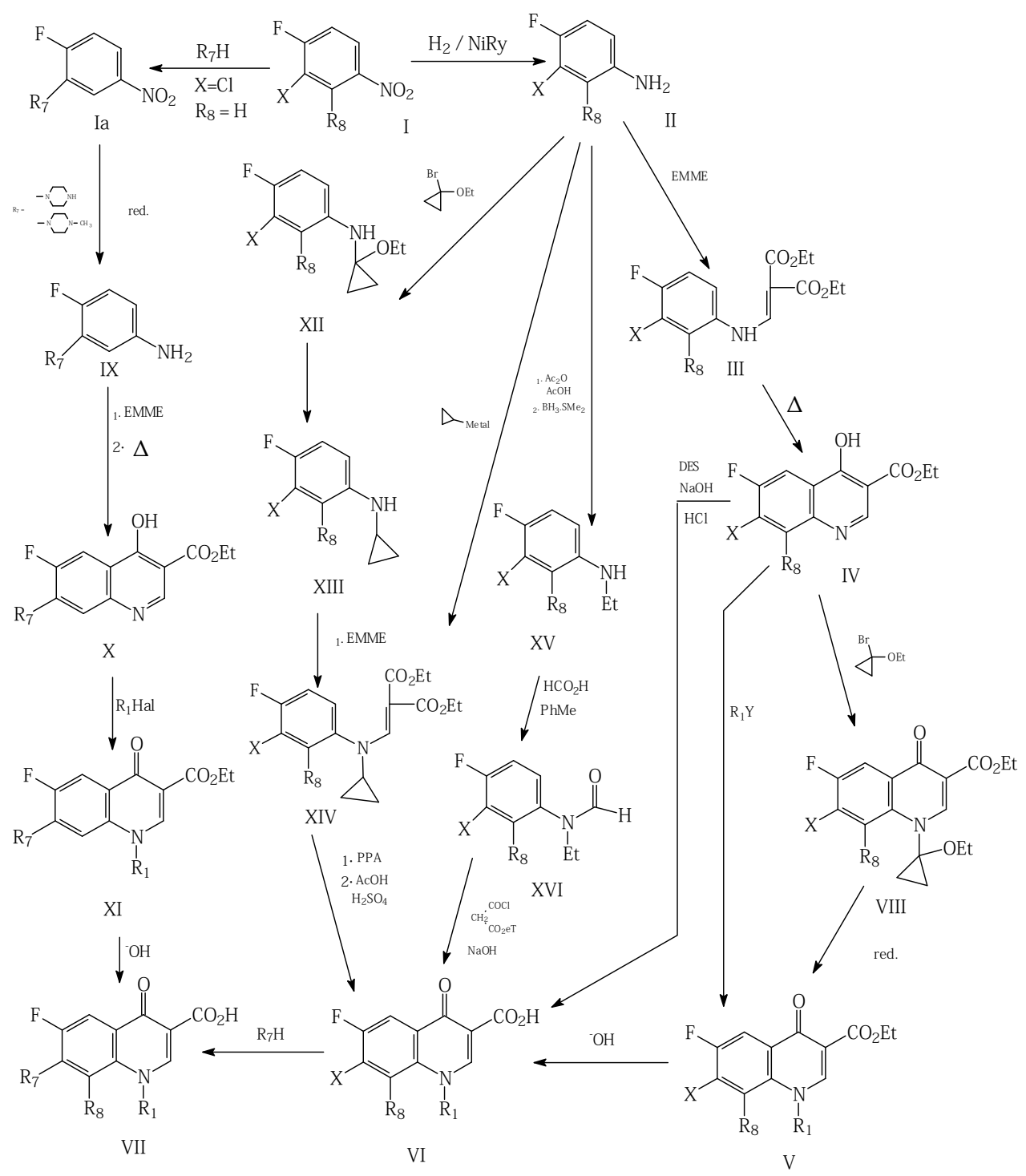

Fig. 11. Gould-Jacobs method.

Method requiers the reaction of isatoic anhydride with sodium ethyl formyl acetate

Another synthesis method requiers the reaction of isatoic anhydride with sodio ethyl formyl acetate (Figure 13). 2,4,5-trihalobenzoic acid (XX) is reacted with an appropiate amine, and then is treated with the compound : $\mathrm{R}_{2} \mathrm{R}_{3} \mathrm{CO}\left(\mathrm{R}_{2}=\mathrm{R}_{3}=\mathrm{Cl}, \mathrm{CCl}_{3} \mathrm{O}\right.$ or $\mathrm{R}_{2}=\mathrm{C}_{1-10}$ alkyl and $\mathrm{R}_{3}=$ $\mathrm{Cl})$ to produce benzoxazindione (XXII). The benzoxazindione (XXII) is then condensed with compound $\left(\mathrm{HOCH}=\mathrm{CHCO}_{2} \mathrm{Et}\right)$ to provide key compound $(\mathrm{V})$. 


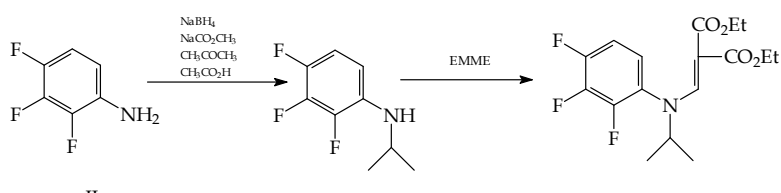

IIa

XVII

XVIII

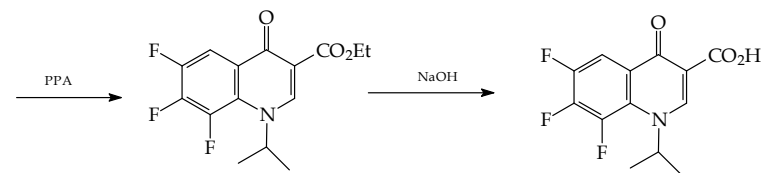

XIX

VIa

Fig. 12. The modified Gould-Jacobs method.
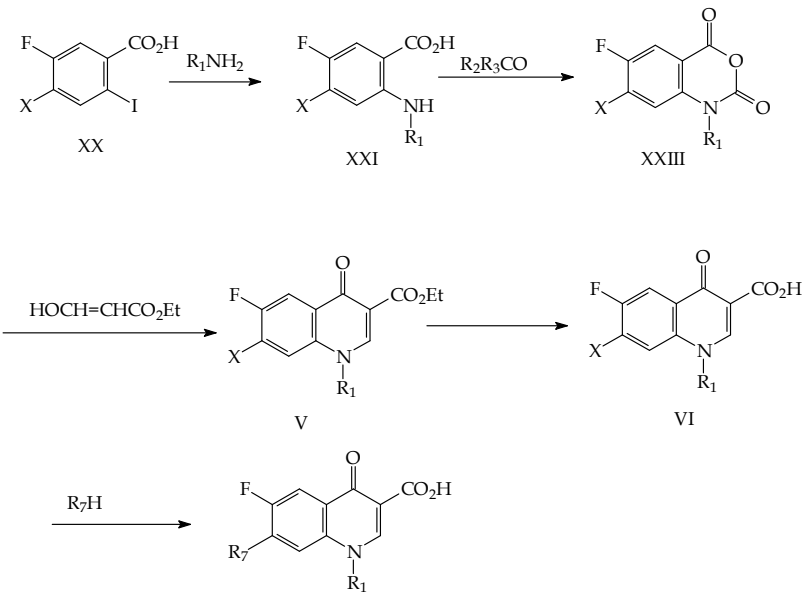

VII

Fig. 13. Method requiers the reaction of isatoic anhydride with sodium ethyl formyl acetate

Intramolecular nucleophilic displacement cyclization route to quinolones (a)

An efficient and regiospecific synthesis via an intramolecular nucleophilic displacement cyclization reaction was reported. (Chu,1985) (Figure 14).

Key compund (III) can be obtained by:

- reaction of benzoic acid chloride (I) with ethyl malonic acid; the compound (II) give the compund (III).(Petersen \& Grohe 1984a), (Petersen \& Grohe 1984b),

- acetophenone (Ia) is condensed with diethyl carbonate in the presence of sodium hydride(Chu et al. 1985) 

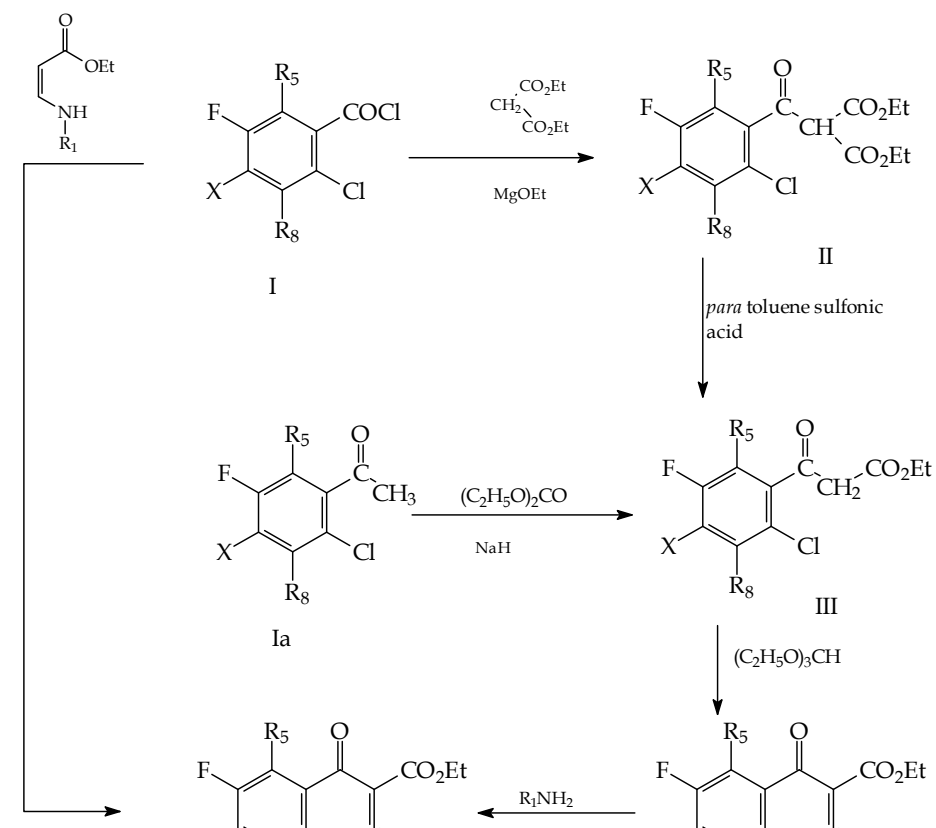

Ia $\left(\mathrm{C}_{2} \mathrm{H}_{5} \mathrm{O}\right)_{3} \mathrm{CH}$<smiles>[Y]NC[C@H](C(=O)OCC)[C@H](O)c1c([R3])c(F)c([X])c([R3])c1Cl</smiles><smiles>[Y]C1=CC(C(=O)O)C(OCC)c2cc(F)c([X])cc21</smiles>

VI IV<smiles>[R]c1cc2c(cc1F)c(=O)c(C(=O)O)cn2[Y1]</smiles>

VII

Fig. 14. Intramolecular nucleophilic displacement cyclization route to quinolones (a).

Intermediates (III) reacts with acetic anhydride in the presence trietilortoformiate to produce 3-ethoxy-2-benzoyl-ethyl acrylate (IV). Compound (IV) is further reacted with an appropriate amine in dichloromethane at room temperature to provide 3-anilino-2-benzoylethyl acrylate (IVa).

Compound (IVa) can be also obtained directly from benzoic acid chloride (I). (Chu \& Fernandes 1991).

Treatment with a base induces cyclization to produce the quinolone (V). 
Intramolecular nucleophilic displacement cyclization route to quinolones (b)

A synthesis method similar to that described above is shown in Figure 15. This method involves intramolecular cyclization of the compound (VIII).(Egawa et al. 1987).
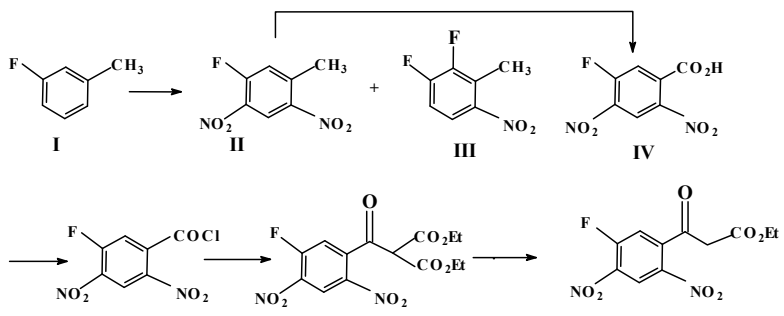

VI

VII a
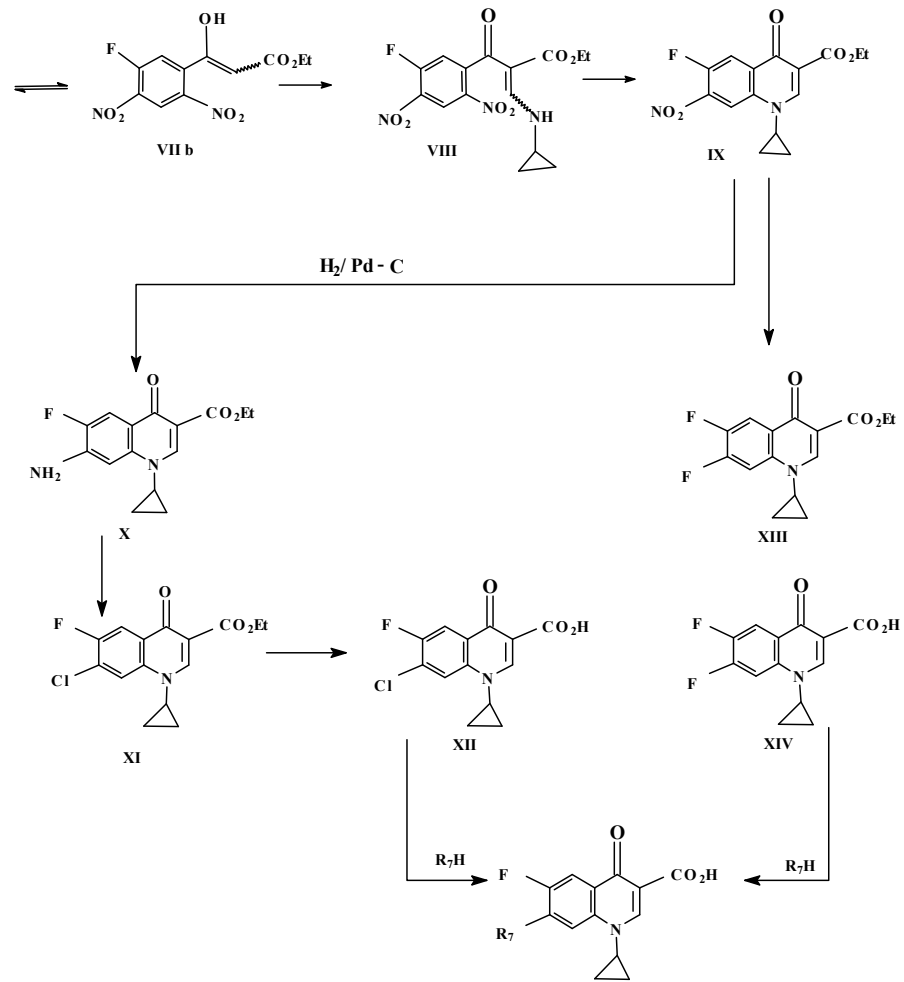

XV

Fig. 15. Intramolecular nucleophilic displacement cyclization route to quinolones (b).

\subsection{Structure of the new compounds}

This paper presents experimental data regarding the synthesis of several quinolones with general formula: (Figure 16) 
<smiles>[R]c1cc2c(=O)c(C(=O)O)cn([R1])c2c([R3])c1[R]</smiles>

Fig. 16. The structure of the new compounds.

$\mathrm{R}_{1}=$ ethyl, isopropyl, 2-buthyl, 2-penthyl, benzyl, alyl, $p$-nitro-phenyl, $p$-amino-phenyl;

$\mathrm{R}_{6}=$ hydrogen, fluor, chlor, methyl;

$\mathrm{R}_{7}=$ 3-methyl-piperazinyl, 4-methyl-piperazinyl, piperidinyl, 3-methyl-piperidinyl, 4-methyl-piperidinyl, pirolidinyl, morpholinyl, homopiperazinyl;

$\mathrm{R}_{8}=$ hydrogen, chlor, methyl. methoxy, nitro

\subsection{Synthesis pathway}

The synthesis of the novel quinolones followed a Gould-Jacobs cyclization process (Figure 17). An appropriate unsubstituted aniline (1) is reacted with diethylethoxy methylene malonate (EMME) to produce the resultant anilinomethylenemalonate (2). A subsequent thermal process induces Gould-Jacobs cyclization to afford the corresponding 4-hidroxyquinoline-3-carboxylate ester (3). ( $\mathrm{R}_{6}=$ fluoro, chloro, methyl, hydrogen) (Pintilie et al. 2009a) (Pintilie et al. 2009b),(Pintilie et al. 2010).

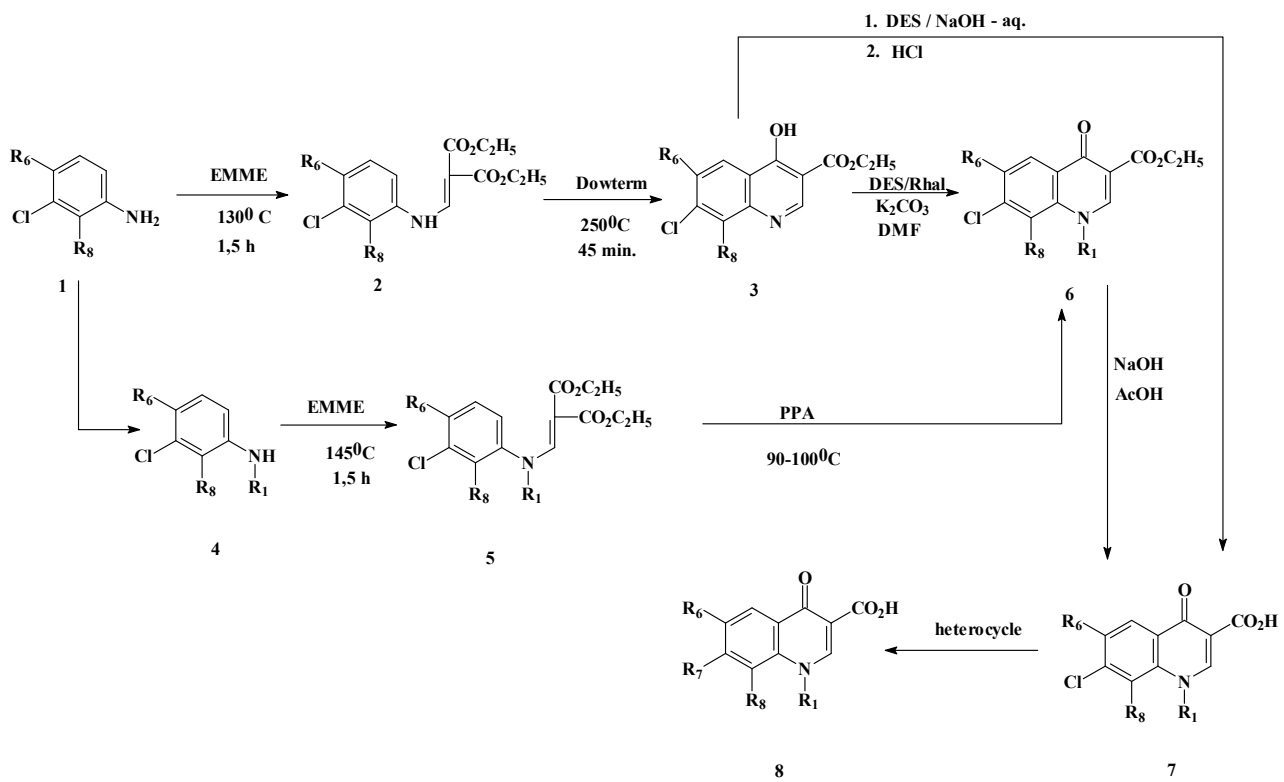

Fig. 17. Synthesis of the new quinolones.

The following operation is the alkylation of the 4-hidroxy-quinoline-3-carboxylate ester (3). which is usually accomplished by reaction with a suitable alkyl halide, dialkyl sulphates, aril 
halide to produce the qinolone 3-carboxylate ester (6). ( $\mathrm{R}_{1}=$ ethyl, alyl, benzyl, $p$-nitrophenyl) (Pintilie et al. 2003a) (Pintilie et al. 2003b),(Pintilie et al. 2003c)(Pintilie \& Nita 2011).

A modified approach resorts to the use of a monosubstitued aniline (4) as a starting material which avoids subsequent $\mathrm{N}$-1-amine alkylation $\left(\mathrm{R}_{1}=\right.$ isopropyl, 2-butyl, 2-pentyl). (Pintilie et al. 2009a) (Pintilie et al. 2009b),(Pintilie et al. 2010). A strong acid (such as polyphosphoric acid) is often needed to induce cyclization directly resulting in the formation of N-isopropyl4-oxo-quinolone-3-carboxylate ester (6) ( $\mathrm{R}_{1}=$ isopropyl, 2-butyl, 2-pentyl). In either case, the final manipulation is acid or basic hydrolysis to cleave the ester generating the biologically active free carboxylic acid (7). The biologically active free carboxylic acid (7) was also obtained from the corresponding 4-hidroxy-quinoline-3-carboxylate ester (3) by alkylation with dialkyl sulphates in presence of alkali, for example the reaction it can conveniently be carried out in aqueous $40 \%$ sodium hydroxide solution. The displacement of 7-chloro group with a heterocycle yielded compounds (8).

The synthesis of new 1-aryl quinoline-3-carboxilyc acids is according Figure 18. compound (3) $\left(\mathrm{R}_{6}=\mathrm{F}, \mathrm{Cl}, \mathrm{CH}_{3}\right)$ is direct $\mathrm{N}$-arylation. Treatment of (3) with potasium carbonate in DMSO and $p$-fluoro-nitrobenzene yielded 9). The esters were hydrolized to the appropiate acids (10) by refluxing with a mixture of hydrochloric and acetic acids. Upon treatment with a heterocycle yielded compounds (11). The 1-(p-amino-phenyl)-quinoline-3-carboxylic acids (12) can be prepared by a common reduction of nitro group using sodium dithionite.

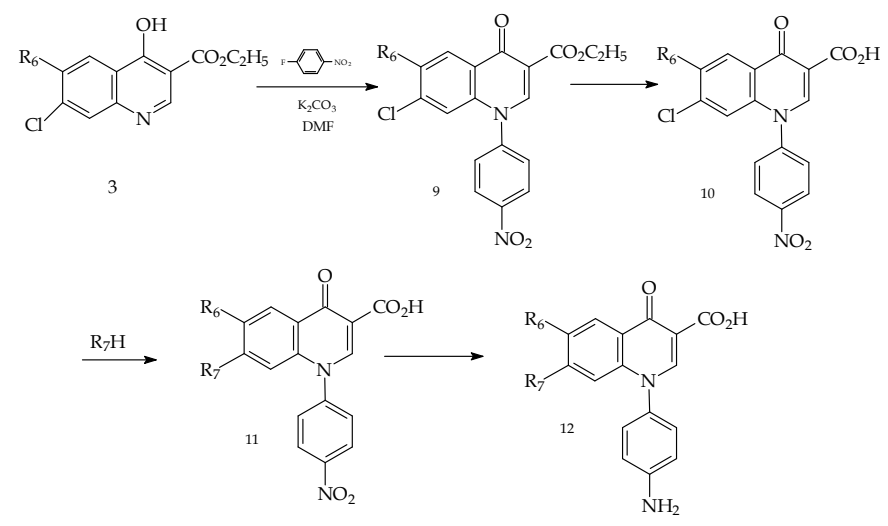

Fig. 18. Sinthesys of 1-aryl-quinolones.

The sinthesys of the new 8-substituted quinoline-3-carboxylic acids is according Figure 19. 8-Chloro-quinoline-3-carboxylic acids (13) was synthesized from 8-unsubstituted qinoline-3carboxilyc acids by chlorination with sulfuryl chloride. 8-Methoxy-quinoline-3-carboxilyc acids (14) was prepared allowing compound (13) to act with alkali metalic alcholate.

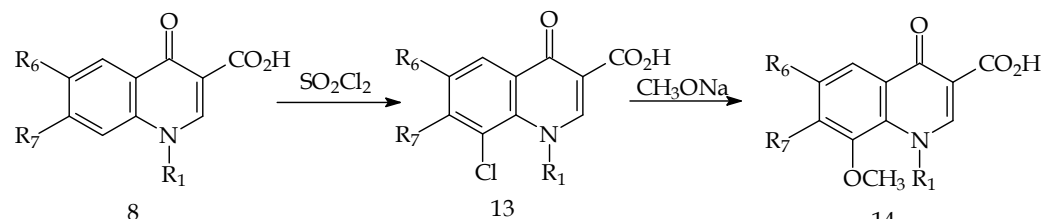

Fig. 19. Sinthesys of the new 8-substituted quinoline-3-carboxylic acids. 


\subsection{New compounds: Structure and antimicrobial activity}

\subsubsection{Structure of the new compunds}

A series of new 4-oxo-1,4-dihydro-quinoline-3-carboxylic acids was synthesized. (Figure 20) (Table 1).<smiles>[R]c1cc2c(=O)c(C(=O)O)cn([Y1])c2c([R3])c1[R]</smiles>

Fig. 20. Structure of the new compounds.

\begin{tabular}{|c|c|c|c|c|c|c|}
\hline Quinolones & $\mathrm{R}_{1}$ & $\mathrm{R}_{6}$ & $R_{7}$ & $\mathrm{R}_{8}$ & m.p. $\left({ }^{0} \mathrm{C}\right)$ & Reference \\
\hline $\begin{array}{c}\mathrm{Q} 83 \\
\mathrm{C}_{18} \mathrm{H}_{21} \mathrm{FN}_{2} \mathrm{O}_{3}\end{array}$ & ethyl & $\mathrm{F}$ & 4-methyl-piperidin-1-yl & $\mathrm{H}$ & $235-237$ & $\begin{array}{l}\text { Pintilie et } \\
\text { al. (2003b) }\end{array}$ \\
\hline $\begin{array}{c}\mathrm{Q} 85 \\
\mathrm{C}_{18} \mathrm{H}_{20} \mathrm{ClFN}_{2} \mathrm{O}_{3}\end{array}$ & ethyl & $\mathrm{F}$ & 4-methyl-piperidin-1-yl & $\mathrm{Cl}$ & $201-202,5$ & $\begin{array}{l}\text { Pintilie et } \\
\text { al. (2003b) }\end{array}$ \\
\hline $\begin{array}{c}\text { PQ 1 } \\
\mathrm{C}_{19} \mathrm{H}_{23} \mathrm{FN}_{2} \mathrm{O}_{4}\end{array}$ & ethyl & $\mathrm{F}$ & 4-methyl-piperidin-1-yl & $\mathrm{OCH}_{3}$ & 170 & $\begin{array}{l}\text { Pintilie et } \\
\text { al. (2003b) }\end{array}$ \\
\hline $\begin{array}{c}\text { PQ 12 } \\
\mathrm{C}_{19} \mathrm{H}_{23} \mathrm{FN}_{2} \mathrm{O}_{3}\end{array}$ & iIso-propyl & $\mathrm{F}$ & 4-methyl-piperidin-1-yl & $\mathrm{H}$ & 253 & $\begin{array}{l}\text { Pintilie et } \\
\text { al. (2003b) }\end{array}$ \\
\hline $\begin{array}{c}\text { PQ } 11 \\
\mathrm{C}_{23} \mathrm{H}_{23} \mathrm{FN}_{2} \mathrm{O}_{3}\end{array}$ & benzyl & $\mathrm{F}$ & 4-methyl-piperidin-1-yl & $\mathrm{H}$ & $240-242$ & $\begin{array}{l}\text { Pintilie et } \\
\text { al. (2003b) }\end{array}$ \\
\hline $\begin{array}{c}\mathrm{PQ} 4 \\
\mathrm{C}_{19} \mathrm{H}_{21} \mathrm{FN}_{2} \mathrm{O}_{3}\end{array}$ & alyl & $\mathrm{F}$ & 4-methyl-piperidin-1-yl & $\mathrm{H}$ & $168-170$ & $\begin{array}{l}\text { Pintilie et } \\
\text { al. (2003b) }\end{array}$ \\
\hline $\begin{array}{c}\text { FPQ } 24 \\
\mathrm{C}_{18} \mathrm{H}_{21} \mathrm{FN}_{2} \mathrm{O}_{3} \\
\end{array}$ & ethyl & $\mathrm{F}$ & 3-methyl-piperidin-1-yl & $\mathrm{H}$ & 189,4 & $\begin{array}{l}\text { Pintilie et } \\
\text { al. (2009b) }\end{array}$ \\
\hline $\begin{array}{c}\text { 6ClPQ } 24 \\
\mathrm{C}_{18} \mathrm{H}_{21} \mathrm{ClN}_{2} \mathrm{O}_{3} \\
\end{array}$ & ethyl & $\mathrm{Cl}$ & 3-methyl-piperidin-1-yl & $\mathrm{H}$ & $\begin{array}{r}216,4- \\
218,4 \\
\end{array}$ & $\begin{array}{l}\text { Pintilie et } \\
\text { al. (2009b) }\end{array}$ \\
\hline $\begin{array}{c}\mathrm{PQ} 24 \\
\mathrm{C}_{19} \mathrm{H}_{23} \mathrm{FN}_{2} \mathrm{O}_{3}\end{array}$ & iIso-propyl & F & 3-methyl-piperidin-1-yl & $\mathrm{H}$ & $\begin{array}{l}209,1- \\
211,7\end{array}$ & $\begin{array}{l}\text { Pintilie et } \\
\text { al. (2009b) }\end{array}$ \\
\hline $\begin{array}{c}\text { PQ } 22 \\
\mathrm{C}_{18} \mathrm{H}_{21} \mathrm{FN}_{3} \mathrm{O}_{3} \\
\end{array}$ & iIso-propyl & $\mathrm{F}$ & 3-methyl-piperazin-1-yl & $\mathrm{H}$ & $215-218$ & $\begin{array}{l}\text { Pintilie et } \\
\text { al. (2009b) }\end{array}$ \\
\hline $\begin{array}{c}\text { PQ } 23 \\
\mathrm{C}_{17} \mathrm{H}_{19} \mathrm{FN}_{2} \mathrm{O}_{4} \\
\end{array}$ & iIso-propyl & $\mathrm{F}$ & morpholin-1-yl & $\mathrm{H}$ & $266-268$ & $\begin{array}{l}\text { Pintilie et } \\
\text { al. }(2009 b)\end{array}$ \\
\hline $\begin{array}{c}\text { FPQ } 25 \\
\mathrm{C}_{16} \mathrm{H}_{17} \mathrm{FN}_{2} \mathrm{O}_{4} \\
\end{array}$ & ethyl & $\mathrm{F}$ & morpholin-1-yl & $\mathrm{H}$ & $\begin{array}{l}257,4- \\
258,7 \\
\end{array}$ & $\begin{array}{l}\text { Pintilie et } \\
\text { al. }(2009 b)\end{array}$ \\
\hline $\begin{array}{c}\text { 6ClPQ } 25 \\
\mathrm{C}_{16} \mathrm{H}_{17} \mathrm{ClN}_{2} \mathrm{O}_{4} \\
\end{array}$ & ethyl & $\mathrm{Cl}$ & morpholin-1-yl & $\mathrm{H}$ & $\begin{array}{r}267,1- \\
269,2 \\
\end{array}$ & $\begin{array}{l}\text { Pintilie et } \\
\text { al. (2009b) }\end{array}$ \\
\hline $\begin{array}{c}\text { 6ClPQ } 27 \\
\mathrm{C}_{17} \mathrm{H}_{20} \mathrm{FN}_{3} \mathrm{O}_{3}\end{array}$ & ethyl & $\mathrm{Cl}$ & 3-methyl-piperazin-1-yl & $\mathrm{H}$ & $\begin{array}{l}170,5- \\
171,4\end{array}$ & $\begin{array}{l}\text { Pintilie et } \\
\text { al. (2009b) }\end{array}$ \\
\hline
\end{tabular}




\begin{tabular}{|c|c|c|c|c|c|c|}
\hline Quinolones & $\mathrm{R}_{1}$ & $\mathrm{R}_{6}$ & $\mathrm{R}_{7}$ & $\mathrm{R}_{8}$ & m.p. $\left({ }^{0} \mathrm{C}\right)$ & Reference \\
\hline $\begin{array}{c}\text { FPQ } 28 \\
\mathrm{C}_{16} \mathrm{H}_{16} \mathrm{ClFN}_{2} \mathrm{O}_{4}\end{array}$ & ethyl & $\mathrm{F}$ & morpholin-1-yl & $\mathrm{Cl}$ & $244,6-244$ & $\begin{array}{l}\text { Pintilie et } \\
\text { al. }(2009 b)\end{array}$ \\
\hline $\begin{array}{c}\text { 6MeQ } 83 \\
\mathrm{C}_{19} \mathrm{H}_{24} \mathrm{~N}_{2} \mathrm{O}_{3}\end{array}$ & ethyl & $\mathrm{CH}_{3}$ & 4-methyl-piperidin-1-yl & $\mathrm{H}$ & $240-242$ & $\begin{array}{l}\text { Pintilie et } \\
\text { al. (2003a) }\end{array}$ \\
\hline $\begin{array}{c}\text { 6MePQ } 12 \\
\mathrm{C}_{20} \mathrm{H}_{26} \mathrm{~N}_{2} \mathrm{O}_{3}\end{array}$ & iIso-propyl & $\mathrm{CH}_{3}$ & 4-methyl-piperidin-1-yl & $\mathrm{H}$ & $234-235$ & $\begin{array}{l}\text { Pintilie et } \\
\text { al. (2003a) }\end{array}$ \\
\hline $\begin{array}{c}\text { 6MePQ } 11 \\
\mathrm{C}_{24} \mathrm{H}_{26} \mathrm{~N}_{2} \mathrm{O}_{3}\end{array}$ & benzyl & $\mathrm{CH}_{3}$ & 4-methyl-piperidin-1-yl & $\mathrm{H}$ & $218-220$ & $\begin{array}{l}\text { Pintilie et } \\
\text { al. (2003a) }\end{array}$ \\
\hline $\begin{array}{c}\text { 6MePQ } 4 \\
\mathrm{C}_{20} \mathrm{H}_{24} \mathrm{~N}_{2} \mathrm{O}_{3}\end{array}$ & alyl & $\mathrm{CH}_{3}$ & 4-methyl-piperidin-1-yl & $\mathrm{H}$ & $244-246$ & $\begin{array}{l}\text { Pintilie et } \\
\text { al. (2003a) }\end{array}$ \\
\hline $\begin{array}{c}\mathrm{HQ} \mathrm{83} \\
\mathrm{C}_{18} \mathrm{H}_{22} \mathrm{FN}_{2} \mathrm{O}_{3}\end{array}$ & ethyl & $\mathrm{H}$ & 4-methyl-piperidin-1-yl & $\mathrm{H}$ & $240-242$ & $\begin{array}{l}\text { Pintilie et } \\
\text { al. (2003c) }\end{array}$ \\
\hline $\begin{array}{c}\mathrm{HPQ} 12 \\
\mathrm{C}_{19} \mathrm{H}_{24} \mathrm{~N}_{2} \mathrm{O}_{3}\end{array}$ & iIso-propyl & $\mathrm{H}$ & 4-methyl-piperidin-1-yl & $\mathrm{H}$ & $234-235$ & $\begin{array}{l}\text { Pintilie et } \\
\text { al. (2003c) }\end{array}$ \\
\hline $\begin{array}{c}\text { HPQ 11 } \\
\mathrm{C}_{23} \mathrm{H}_{24} \mathrm{~N}_{2} \mathrm{O}_{3}\end{array}$ & benzyl & $\mathrm{H}$ & 4-methyl-piperidin-1-yl & $\mathrm{H}$ & $218-220$ & $\begin{array}{l}\text { Pintilie et } \\
\text { al. (2003c) }\end{array}$ \\
\hline $\begin{array}{c}\mathrm{HPQ} 4 \\
\mathrm{C}_{19} \mathrm{H}_{22} \mathrm{~N}_{2} \mathrm{O}_{3}\end{array}$ & alyl & $\mathrm{H}$ & 4-methyl-piperidin-1-yl & $\mathrm{H}$ & $244-246$ & $\begin{array}{l}\text { Pintilie et } \\
\text { al. (2003c) }\end{array}$ \\
\hline $\begin{array}{c}\text { HPQ } 21 \\
\mathrm{C}_{18} \mathrm{H}_{23} \mathrm{~N}_{3} \mathrm{O}_{3}\end{array}$ & iIso-propyl & $\mathrm{H}$ & 4-methyl-piperazin-1-yl & $\mathrm{H}$ & $239-240$ & $\begin{array}{l}\text { Pintilie et } \\
\text { al. (2009a) }\end{array}$ \\
\hline $\begin{array}{c}\text { HPQ } 24 \\
\mathrm{C}_{18} \mathrm{H}_{22} \mathrm{~N}_{2} \mathrm{O}_{3}\end{array}$ & ethyl & $\mathrm{H}$ & 3-methyl-piperidin-1-yl & $\mathrm{H}$ & $\begin{array}{l}190,1- \\
192,1\end{array}$ & $\begin{array}{l}\text { Pintilie et } \\
\text { al. (2009a) }\end{array}$ \\
\hline $\begin{array}{c}\text { HPQ } 25 \\
\mathrm{C}_{16} \mathrm{H}_{18} \mathrm{~N}_{2} \mathrm{O}_{4}\end{array}$ & ethyl & $\mathrm{H}$ & morpholin-1-yl & $\mathrm{H}$ & $267,3-269$ & $\begin{array}{l}\text { Pintilie et } \\
\text { al. (2009a) }\end{array}$ \\
\hline $\begin{array}{c}\text { HPQ } 27 \\
\mathrm{C}_{17} \mathrm{H}_{21} \mathrm{~N}_{3} \mathrm{O}_{3}\end{array}$ & ethyl & $\mathrm{H}$ & 3-methyl-piperazin-1-yl & $\mathrm{H}$ & $\begin{array}{l}191,3- \\
192,6\end{array}$ & $\begin{array}{l}\text { Pintilie et } \\
\text { al. (2009a) }\end{array}$ \\
\hline $\begin{array}{c}\text { HPQ } 31 \\
\mathrm{C}_{19} \mathrm{H}_{24} \mathrm{~N}_{2} \mathrm{O}_{3}\end{array}$ & 2-butyl & $\mathrm{H}$ & 4-methyl-piperidin-1-yl & $\mathrm{H}$ & $181,4-183$ & $\begin{array}{l}\text { Pintilie et } \\
\text { al. (2009a) }\end{array}$ \\
\hline $\begin{array}{c}\text { HPQ } 51 \\
\mathrm{C}_{19} \mathrm{H}_{24} \mathrm{~N}_{2} \mathrm{O}_{3}\end{array}$ & 2-pentyl & $\mathrm{H}$ & 4-methyl-piperidin-1-yl & $\mathrm{H}$ & $\begin{array}{l}138,5- \\
140,5\end{array}$ & $\begin{array}{l}\text { Pintilie et } \\
\text { al. (2009a) }\end{array}$ \\
\hline $\begin{array}{c}\mathrm{PQ}_{3} \\
\mathrm{C}_{22} \mathrm{H}_{20} \mathrm{FN}_{3} \mathrm{O}_{5}\end{array}$ & $\begin{array}{l}p \text {-nitro- } \\
\text { phenyl }\end{array}$ & $\mathrm{F}$ & 4-methyl-piperidin-1-yl & $\mathrm{H}$ & 204-206 & $\begin{array}{c}\text { Pintilie\& } \\
\text { Nita (2011) } \\
\end{array}$ \\
\hline $\begin{array}{c}\mathrm{PQ} 7 \\
\mathrm{C}_{21} \mathrm{H}_{19} \mathrm{FN}_{4} \mathrm{O}_{5} \\
\end{array}$ & $\begin{array}{l}p \text {-nitro- } \\
\text { phenyl }\end{array}$ & $\mathrm{F}$ & Homopiperazin-1-yl & $\mathrm{H}$ & $128-130$ & $\begin{array}{c}\text { Pintilie\& } \\
\text { Nita (2011) } \\
\end{array}$ \\
\hline $\begin{array}{c}6 \mathrm{ClPQ}^{3} \\
\mathrm{C}_{22} \mathrm{H}_{20} \mathrm{ClN}_{3} \mathrm{O}_{5}\end{array}$ & $\begin{array}{l}p \text {-nitro- } \\
\text { phenyl }\end{array}$ & $\mathrm{Cl}$ & 4-methyl-piperidin-1-yl & $\mathrm{H}$ & 202-205 & $\begin{array}{c}\text { Pintilie\& } \\
\text { Nita (2011) }\end{array}$ \\
\hline $\begin{array}{c}\text { 6MePQ } 3 \\
\mathrm{C}_{23} \mathrm{H}_{23} \mathrm{~N}_{3} \mathrm{O}_{5}\end{array}$ & $\begin{array}{l}p \text {-nitro- } \\
\text { phenyl }\end{array}$ & $\mathrm{CH}_{3}$ & 4-methyl-piperidin-1-yl & $\mathrm{H}$ & $222-224$ & $\begin{array}{c}\text { Pintilie\& } \\
\text { Nita (2011) }\end{array}$ \\
\hline $\begin{array}{c}\mathrm{APQ} 3 \\
\mathrm{C}_{22} \mathrm{H}_{22} \mathrm{FN}_{3} \mathrm{O}_{3}\end{array}$ & $\begin{array}{c}p \text {-amino- } \\
\text { phenyl }\end{array}$ & $\mathrm{F}$ & 4-methyl-piperidin-1-yl & $\mathrm{H}$ & $284-285,5$ & $\begin{array}{c}\text { Pintilie\& } \\
\text { Nita (2011) }\end{array}$ \\
\hline $\begin{array}{l}\text { A6MePQ } 3 \\
\mathrm{C}_{23} \mathrm{H}_{22} \mathrm{~N}_{3} \mathrm{O}_{3}\end{array}$ & $\begin{array}{c}p \text {-amino- } \\
\text { phenyl }\end{array}$ & $\mathrm{CH}_{3}$ & 4-methyl-piperidin-1-yl & $\mathrm{H}$ & $250-253$ & $\begin{array}{c}\text { Pintilie\& } \\
\text { Nita (2011) }\end{array}$ \\
\hline
\end{tabular}

Table 1. 4-Oxo-1,4-dihydro-quinoline-3-carboxylic acids synthesized in this paper. 


\subsubsection{Antibacterial activity of the new compunds}

The new compounds were evaluated for "in vitro" activity by determining minimum inhibitory concentration against of bacteria Escherichia. Coli, Staphylococcus. Aureus and Pseudomonas .aeruginosa, by agar dilution method (Buiuc 1998) (NCCLS 2003). (Table 2).

\begin{tabular}{|c|c|c|c|c|}
\hline \multirow[t]{2}{*}{ Quinolone } & \multicolumn{3}{|c|}{$\begin{array}{l}\text { Minimum inhibitory concentration } \\
\mu \mathrm{g} / \mathrm{ml}\end{array}$} & \multirow[t]{2}{*}{ Referances } \\
\hline & E. coli & S. aureus & P. aeruginosa & \\
\hline Q 83 & 3,12 (a) & $1,56(\mathrm{c})$ & $6,25(\mathrm{e})$ & Pintilie et al. (2003b) \\
\hline Q 85 & $3,12(a)$ & $0,39(\mathrm{c})$ & 6,25 (e) & Pintilie et al. (2003b) \\
\hline PQ 1 & $3,12(a)$ & $0,78(\mathrm{c})$ & $3,12(\mathrm{e})$ & Pintilie et al. (2003b) \\
\hline PQ 4 & 12,5 (a) & $1,56(\mathrm{c})$ & $6,25(\mathrm{e})$ & Pintilie et al. (2003b) \\
\hline FPQ 24 & $2,00(a)$ & $0,50(b)$ & $32,00(\mathrm{~d})$ & Pintilie et al. (2009b) \\
\hline 6CIPQ 24 & $8,00(a)$ & $2,00(b)$ & $>128(\mathrm{~d})$ & Pintilie et al. (2009b) \\
\hline PQ 24 & $8,00(a)$ & $2,00(b)$ & $64,00(\mathrm{~d})$ & Pintilie et al. (2009b) \\
\hline PQ 22 & 0,50 (a) & $4,00(b)$ & $8,00(\mathrm{~d})$ & Pintilie et al. (2009b) \\
\hline 6CIPQ 25 & 4,00 (a) & $2,00(b)$ & $128(\mathrm{~d})$ & Pintilie et al. (2009b) \\
\hline FPQ 25 & $0,125(a)$ & $0,06(b)$ & $8,00(\mathrm{~d})$ & Pintilie et al. (2009b) \\
\hline FPQ 28 & 0,125 (a) & $0,06(b)$ & $8,00(\mathrm{~d})$ & Pintilie et al. (2009b) \\
\hline HPQ 21 & $8,00(\mathrm{a})$ & $64,00(b)$ & $>128(\mathrm{~d})$ & Pintilie et al. (2009a) \\
\hline HPQ 25 & $8,00(a)$ & $64,00(b)$ & $>128(\mathrm{~d})$ & Pintilie et al. (2009a) \\
\hline HPQ 27 & $>128$ (a) & $32,00(b)$ & $>128(\mathrm{~d})$ & Pintilie et al. (2009a) \\
\hline PQ 3 & $12,50(\mathrm{a})$ & $25,00(\mathrm{c})$ & $12,50(\mathrm{e})$ & Pintilie\& Nita (2011) \\
\hline APQ 3 & 12,50 (a) & $0,78(\mathrm{c})$ & $12,50(\mathrm{e})$ & Pintilie\& Nita (2011) \\
\hline PQ 7 & 12,50 (a) & 3,12 (c) & $12,50(\mathrm{e})$ & Pintilie\& Nita (2011) \\
\hline
\end{tabular}

a. Escherichia. coli ATCC 25922, b. Staphylococcus. aureus ATCC29213, c. Staphylococcus. aureus ATCC29223, d. Pseudomonas .aeruginosa ATCC27813,e. Pseudomonas .aeruginosa ATCC27853

Table 2. "In vitro" antibacterial activity of the new quinolones.

\section{Conclusion}

In conclusion, were synthesized new quinolones and was investigated their antibacterial activity. The results indicate that substituent combinations in the quinolone ring, might produce powerful antibacterial agents such as compound: FPQ-28 (1-ethyl-6-fluoro-7morpholinyl-8-chloro-1,4-dihydro-4-oxo-quinoline-3-carboxylic acid), (Figure 21) in concordance with the QSARs studies (Tarko et al. 2008), showed excellent „in vitro" activity against E. Coli ATCC 25922 (MIC 0,125 $\mu \mathrm{g} / \mathrm{mL}$ ) and S.aureus ATCC29213 (MIC $0,06 \mu \mathrm{g} / \mathrm{mL})$. 
<smiles>CCn1cc(C(=O)O)c(=O)c2cc(F)c(N3CCOCC3)c(Cl)c21</smiles>

Fig. 21. 1-Ethyl-6-fluoro-7-morpholinyl-8-chloro-1,4-dihydro-4-oxo-quinoline-3-carboxylic acid -FPQ 28

${ }^{1} \mathrm{H}-\mathrm{NMR}(\mathrm{dmso}-\mathrm{d} 6, \delta$ ppm, J Hz): 8.97(s, 1H, H-2); 8.07(d, 1H, H-5, 11.8); 4.89(q, 2H, H-17, 7.2); 3.82(m, $4 \mathrm{H}$, sist. $\left.\mathrm{A}_{2} \mathrm{~B}_{2}, \mathrm{H}-13-15\right)$; 3.37(m, $4 \mathrm{H}$, sist. $\left.\mathrm{A}_{2} \mathrm{~B}_{2}, \mathrm{H}-12-16\right) ; 1.46(\mathrm{t}, 3 \mathrm{H}, \mathrm{H}-18,7.2)$. ${ }^{13} \mathrm{C}-\mathrm{NMR}(\mathrm{dmso}-\mathrm{d} 6, \delta \mathrm{ppm}, J \mathrm{~Hz})$ : 175.56(C-4); 166.12(C-21); 154.95(d, J(133-19F) $=254.8$, C6);158.37(Cq); 153.04(C-2); 125.94(Cq); 124.76(Cq); 116.86(Cq); 111.57(d, J(13. C-19F)=23.5, C-5); 98.35(C-3); 67.23(C-13-15); 53.64(C-12-16); 51.58(C-17); 16.14(C-18).

FT-IR(solid in ATR, v cm-1): 3056; 2957; 2895; 2849; 1717; 1615; 1558; 1532; 1492; 1435; 1376; $1300 ; 1253 ; 1207 ; 1102 ; 1033 ; 980 ; 920 ; 890 ; 846 ; 803 ; 740 ; 651 ; 528 ; 464$.

\section{References}

Brighty, K \& Gootz, T. (2000) Chemistry and Mechanism of action of the quinolone antibacterial, In: The Quinolones Third Edition, Vincent Andriole, pp. 33-97, Academic Press, ISBN 978-0-12-059517-4

Chu, D.T.W., Fernandes P., Claiborne, A.K., Pihuleac, E., Norden, C.W., Maleczka, J.R.E. \& Pernet, A.G. (1985). Synthesis and structure-activity relationships of novel arylfluoroquinolone antibacterial agents. Journal of Medicinal Chemistry, Vol. 28, No.12, (dec. 1985), pp. 1558-1564, ISSN-0022-2623

Chu, D.T.W. \& Fernandes, P. (1991). Recent developments in the field of quinolone antibacterial agents, In : Advances in drug research Vol. 21, Bernard Testa, pp. 39-144, Academic Press, ISBN 0-12-013321-0, London ; San Diego ; New York

Domagala, J.M., Heifetz, C.L., Mich, T.F. \& Nichols, J.B., (1986) 1-Ethyl-7-[3[(ethylamino)methyl]-1-pyrrolidinyl]-6,8-difluoro-1,4-dihydro-4-oxo-3-quinoline carboxylic acid. New quinolone antibacterial with potent gram-positive activity. Journal of Medicinal Chemistry, Vol. 29, No. 4, (apr. 1986), pp. 445-448, ISSN-00222623

Buiuc, D. (1998) Determinarea sensibilității la medicamente antimicrobiene: tehnici cantitative, în "Microbiologie clinică", vol. I, 1998, pp. 438-442. Editura Didactică şi Pedagogică, Bucureşti.

Egawa, H., Kataoka, M., Shibamori K., Miyamoto, J.N. \& Matsumoto, J. (1987) A new synthetic route to 7-halo-1-cyclopropyl-6-fluoro-1,4-dihydro-4-oxoquinoline-3carboxylic acid, an intermediate for the synthesis of quinolone antibacterial agents. Journal of Heterocyclic Chemistry, Vol.24, (1987), pp 181-185, ISSN -0022-152X

Itoh, Y \& Kato, H. (1984) Ger. Offen Patent DE 3433 924 , 1984.

Kazimierozaack, J. \& Pyznar, B. (1987). PL Patent 154 525, 1987.

Koga, H., Itoh, A. \& Murayama, S.,(1980) Structure-activity relationships of antibacterial 6,7and 7,8-disubstituted 1-alkyl-1,4-dihydro-4-oxoquinoline-3-carboxylic acids. Journal of Medicinal Chemistry, Vol. 23, No.12, (dec. 1980), pp. 1358-1363, ISSN-0022-2623 
Lesher, G. Y., Foelich, E. J., Garnett, M. D., Bayley, J. H. \& Brundage, P. R., (1962). 1,8 Naphtyridine derivatives, a new class of chemotherapeutic agents. Journal of Medicinal Chemistry, Vol. 5, No. 5, (sept. 1962), pp. 259-279, ISSN-0022-2623

McGuirk, P.R. (1989), EP Patent, EP 0348 099, 1989.

Petersen, U. \& Grohe, K. (1984a). Ger. Offen Patent DE 32485 05, 1984.

Petersen, U. \& Grohe, K. (1984b). Ger. Offen Patent DE 32485 06, 1984.

Pintilie, L., Oniscu, Draghici, C., Caproiu, M.T., Alexandru, N., Damian, E., Dobrovolschi, D. \& Diaconu, L. (2003a). 6Methyl-quinolones with biological activity. Romanian Biotechnological Letters, Vol. 8, No. 2, (april. 2003), pp 1163-1168. ISSN 1224-5984

Pintilie, L., Oniscu,Voiculescu Gh., Draghici, C., Caproiu, M.T., Alexandru, N., Paraschiv, I., Damian, E., Dobrovolschi, D. \& Diaconu, L. (2003b). Synthesis and antibacterial activity of some novel fluoroquinolones. Romanian Biotechnological Letters, Vol. 8, No. 2, (april. 2003), pp 1197-1204. ISSN 1224-5984

Pintilie, L., Oniscu,Voiculescu Gh., Draghici, C., Caproiu, M.T., Alexandru, N. \& Damian, E., (may 2003). Synthesis of some novel desfluoroquinolones. Romanian Biotechnological Letters, Vol. 8, No. 3 (may.2003), pp. 1303-1309. ISSN 1224-5984

Pintilie, L., Negut, C., Oniscu, C., Caproiu, M.T., \& Nechifor, M. (2009a). Synthesis and antibacterial activity of some novel desfluoroquinolones. Revista de chimie, Vol. 60, No.9, (sept.2009)pp. 871-975, ISSN 0034-7752

Pintilie, L., Negut, C., Oniscu, C., Caproiu, M.T., Nechifor, M, Iancu, L., Ghiciuc, C. \& Ursu R. (2009b). Synthesis and antibacterial activity of some novel quinolones. Romanian Biotechnological Letters, Vol. 14, No. 5, (oct. 2009), pp. 4756-4767, ISSN 1224-5984

Pintilie, L., Nita, S. \& C., Caproiu. (2010). Synthesis of new 7-chloro-8-substituted-1,4dihydro-4-oxo-quinolin-3-carboxylic acids. Revista de chimie, Vol. 61, No.8, (aug.2010) pp. 745-749, ISSN 0034-7752

Pintilie, L. \& Nita S.,(2011). RO Patent application RO A/00554. 15.06.2011

Radl, S. \& Zikan, V. (1989). Synthesis of some 1-aryl-1,4-dihydro-4-oxo-quinoline-3carboxylic acids and their antibacterial activity. Collect. Czech.Chem.Commun., Vol.54, No. 8, (1989), pp 2181-2189, ISSN - 0010-0765

Ramos, G. A. (1994) ES Patent ES 2049 631, 1994.

Ramos, G. A. \& Garcia, N. J. (1994) ES Patent ES 2046 091, 1994.

Saukaita, J.C. \& Gupton, F.B. (1996). U.S. Patent 5430150 (1996)

Sanjose, M.I. \& Ulpiano M. (1986). ES Patent ES 548 375, 1986

Scott, L.D. (1997), Quinolone antibacterial, In: Antibacterial Chemotherapeutic Agents, pp 298345, Blackie Academic\&Professional, London , ISBN 100751402893

Scriewer, M., Petersen, U \& Grohe, K. (1988). Ger. Offen Patent DE 3808 118, 1988.

Segawa, J., Kitano, M., Kazuno,K., Matsuoka,M., Shirahase, I., Ozaki, M., Matsuda, M., Tomii,Y. \& Kise, M. (1992). Studies on pyridonecarboxylic acids. 1. Synthesis and antibacterial evaluation of 7-substituted-6-halo-4-oxo-4H-[1,3]thiazeto[3,2a]quinoline-3-carboxylic acids. . Journal of Medicinal Chemistry, Vol. 35, No.25, (dec. 1992), pp. 4727-4738, ISSN-0022-2623

Tarko, L., Pintilie, L., Negut, C., Oniscu, C. \& Caproiu, M.T. (2008).QSARs on bactericidal activity of 3-carboxy-4-quinolones. Revista de Chimie, Vol. 59, No. 2 (febr. 2008), pp.185-194, ISSN 0034-7752

*** National Committee on Clinical Laboratory Standards (NCCLS) (2003) Antimicrobial Susceptibility Standards (ATS), ed. 2003, for M7 (CMI) şi M100 
(C) 2012 The Author(s). Licensee IntechOpen. This is an open access article distributed under the terms of the Creative Commons Attribution 3.0 License, which permits unrestricted use, distribution, and reproduction in any medium, provided the original work is properly cited. 